Дорошева А.О., Байрамова О.В., Урум Н.С., Медведєва О.Ю.

\title{
ОРГАНІЗАЦЙНИЙ МЕТОД ЗНИЖЕННЯ ВИТРАТ НА ПАЛИВО В ТРАНСПОРТНИХ КОМПАНІЯХ
}

\begin{abstract}
Задача з мінімізачії витрат на паливо стає першочерговою в системі управління витратами транспортних компаній. В статті розглянуті такі методичні принципи планування в суднохідній компанії, як збалансованість, ефективність, варіантність, оптимальність, ієрархічність, динамічність, та планомірність. Доведено необхідність впровадження адаптивної трьохрівневої системи планування: навігаційного, оперативного та рейсового рівнів. Розглянуто структуру витрат суднохідної компанії. Показано, щзо близько третини витрат у транспортних компаніях відноситься до витрат на паливо. $B$ статті доведено, що існують технічні і організаційні методи зниження витрат на паливо в транспортних компаніях. Організаційні методи пов'язані зі змінами в процесі планування витрат в цілому. Показано, щзо на сьогоднішній день при плануванні потреби палива в судноплавних компаніях установлюються норми витрати палива, виходячи з даних минулої навігаиї (з корегуванням на зміни обсягу роботи-вантажообігу). Запропоновано для планування витрат на паливо використовувати функціональне та імітаційне моделювання. Функиіональне моделювання допускає опис процесу планування у вигляді чітко структурованих взаємозалежних функиій. При імітаційному моделюванні розглядається процес планування з урахуванням впливу різних зовнішніх $і$ внутрішніх умов, з аналізом динамічних характеристик зміни прочесу $i$ з очінкою ефективності розподілу ресурсів. Використання різних видів моделювання дозволяе сконщентрувати увагу на визначених характеристиках процесу моделювання. 3 метою підвищення якості планування витрат на паливо запропоновано використовувати метод моделювання бізнес-прочесів, в основі якого лежить опис процесу через діі. Прочесний підхід до планування витрат на паливо дозволяє вибудувати логічний взаємозв'язок всіх елементів, властивий процесу планування від початку до його завершення. Наведено існуючий бізнес-процес та розроблено удосконалений бізнеспрочес планування.
\end{abstract}

Ключові слова: бізнес-процеси, витрати на паливо, організаційні методи, принципи планування, процесний підхід, транспортна компанія.

Постановка проблеми. Процеси світової глобалізації визначають значне зростання конкуренції у всіх галузях економіки. Застосування ефективних методів управління, побудованих на сучасних принципах та концепціях відповідно до сучасного рівня розвитку науки, техніки і технологій, є безумовною вимогою проведення економічних перетворень в Україні.

Важливим аспектом у розгляді питання побудови ефективної системи менеджменту сучасної організації $є$ питання управління витратами підприємства. Ефективне управління витратами дозволяє мінімізувати їх і забезпечити задану рентабельність підприємства. Рішення завдання управління витратами пов'язується зі створенням системи обліку і контролю, що в підсумку, дає можливість транспортній компанії володіти якісною інформацією про свої витрати і виявити потенційні власні резерви для їх подальшої реалізації.

Водний транспорт України, з огляду на особливості територій, $є$ важливою складовою економіки країни. Внутрішні водні артерії здатні забезпечити перевезення значних вантажів. Особливо важливим водний транспорт стає при транспортуванні сільськогосподарської продукції з внутрішніх районів України до портів півдня (Одеси). Підвищення ефективності діяльності транспортних компаній представляє собою актуальне науково-економічне 
завдання, рішення якого повинно значною мірою вплинути на розвиток транспортного комплексу країни.

Задача 3 мінімізації витрат на паливо стає першочерговою в системі управління витратами транспортних компаній.

Відзначимо, що існуючі методи управління, які застосовуються, і інформаційна база в плануванні витрат транспортної компанії, яка використовується, недостатньо адаптовані до ринкових умов. Так, планування експлуатаційних витрат на паливо грунтується тільки на даних про минулу навігацію і не враховує особливості поточної навігації.

Досить обмежено використовуються економіко-математичні методи моделювання, що дозволяють отримати кореляційні залежності факторів, які впливають на витрату палива та визначити напрямки його економії. Низьким залишається i використання сучасних інформаційних технологій, що в умовах їх стрімкого розвитку, робить результати процесу планування свідомо не раціональними.

Аналіз останніх досліджень і публікацій. Питання зменшення витрат на паливо в транспортних компаніях досліджувалися з середини XX століття. Основними напрямками дослідження було технічне регулювання руху транспортних засобів, дослідження ефективності пропульсивного комплексу. Відмітимо таких авторів в даних дослідженнях як Є.А. Григорьєв [1], Г.В. Захарова [2], Grimmelius Н. [3], Шимко К.Н. [4], Т.В. Тарасенко [5], Ю.А.Лисняк [6]. Існує ряд робіт які присвячені питанню оперативного планування роботи транспортної компанії (флоту), до яких можна віднести дослідження: А.Ю.Платова [7], В.Н. Тверитина [8], Michalsky, Jan P. [9].

У той же час, комплексного методу планування експлуатаційних витрат на паливо в транспортних компаніях, що дозволило б внести економію засобів, знайдено не було. Відзначені обставини послужили підставою для вибору теми статті та дозволили визначили мету дослідження.

Мета статті $є$ дослідження факторів, що впливають на витрату палива в транспортній компанії, i удосконалення організаційного методу зниження витрат на паливо в транспортних компаніях за рахунок зміни процесу планування.

Викладення основного матеріалу дослідження. У ході економічних реформ, що проводяться в Україні, змінюються і принципи планування, прийняті при командноадміністративній системі господарювання, хоча основні з них залишаються, незважаючи на зміну форм власності. Частину цих принципів можна знайти в науковій i навчальній літературі. У деяких з них розглядаються питання використання системного підходу в господарському керівництві на транспорті і формулюються основні принципи планування розвитку єдиної транспортної системи. Аналіз даних принципів показує, що більшість з них характерні і для водного транспорту та 3 деяким корегуванням можуть бути використані в цієї області. Відповідно до особливостей роботи транспортної компанії дані принципи можна охарактеризувати в такий спосіб (рис. 1).

Методологічні принципи визначають наукові підходи до побудови процесу планування в транспортній компанії.

Принцип збалансованості. На балансі транспортної компанії є визначена кількість технічних засобів, що мають різні можливості в експлуатації. У зв'язку з цим плани роботи підприємства повинні враховувати певні обмеження, тобто повинні бути збалансовані потреби відправників вантажу і можливості транспортної компанії. В іншому випадку підприємство або змушене відмовлятися від виконання частини робіт із транспортування вантажів, або залишати визначену кількість флоту на ремонтно-експлуатаційних базах на холодному відстої, не вводячи цей флот в експлуатацію протягом усієї навігації або іiі частини. 


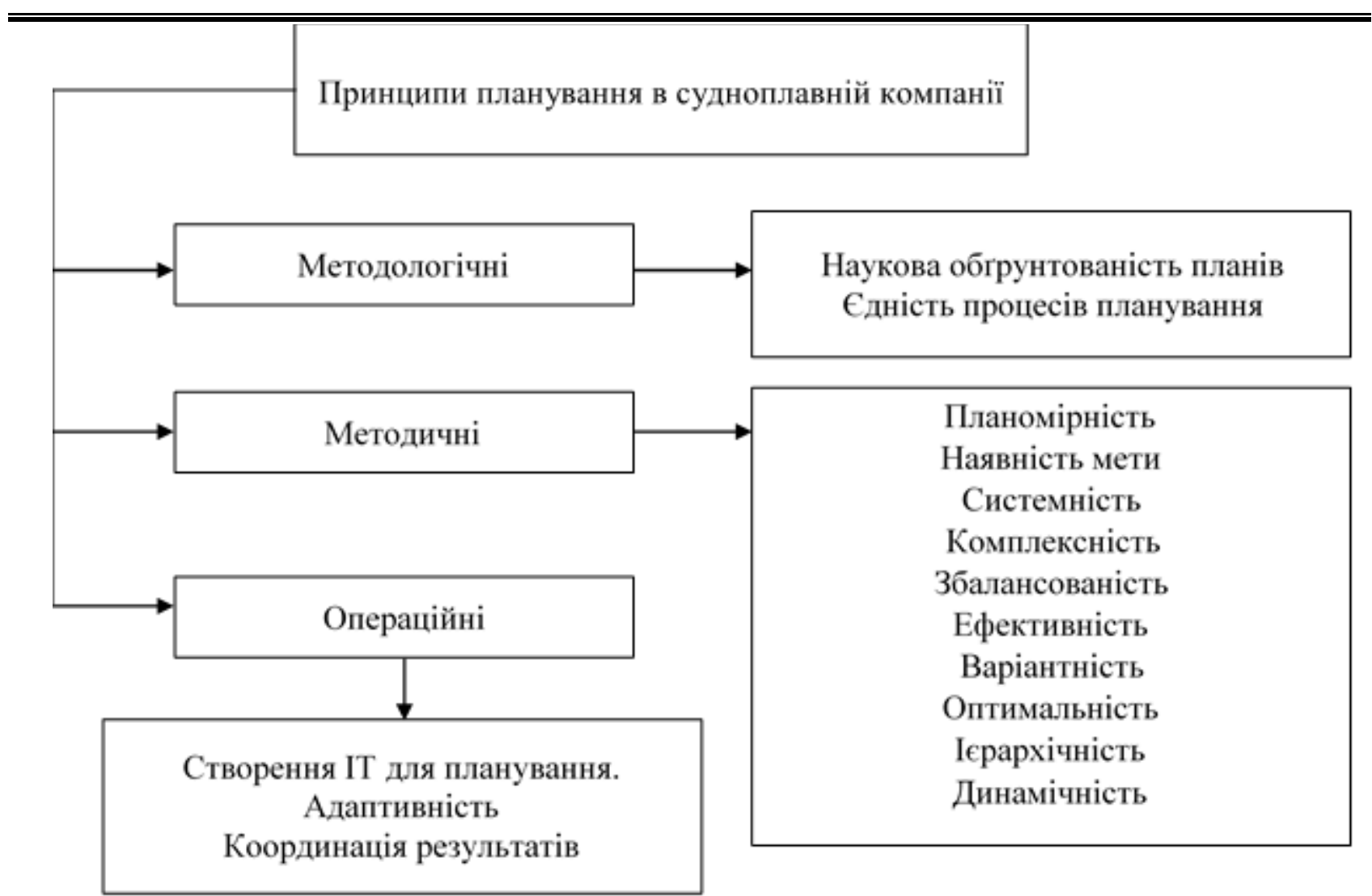

Рисунок 1 - Принципи планування в транспортній компанії

Принцип ефективності. Плани транспортної компанії повинні бути ефективними - доходи від діяльності повинні перевищувати витрати на доставку вантажів при помірних тарифах на перевезення і виконання супровідних робіт. У зв'язку з цим найбільш ефективним способом планування є скорочення експлуатаційних витрат, чому і присвячене дане дослідження.

Принцип варіантності полягає в тому, що задача оптимізації роботи транспортного підприємства i, зокрема технологічного процесу роботи флоту і портів, є різноманітною.

Загальна кількість можливих варіантів використання ресурсів визначається такими параметрами:

- множиною типорозмірів судів і перевантажувальної техніки;

- універсальністю більшості типів флоту, здатністю в одному типі судна перевозити від рейсу до рейсу різні види вантажів;

- множиною варіантів технологій перевезення вантажів і виконання перевантажувальних робіт у пунктах відправлення і призначення;

- змінами умов протягом навігації (глибоководна і мілководна ділянки);

- множиною нормативів використання флоту і перевантажувальної техніки;

- неоднаковими експлуатаційними та економічними показниками роботи флоту різного типу по ділянках його експлуатації і часом використання.

Принцип оптимальності. Аналіз роботи закордонних i вітчизняних транспортних компаній свідчить про те, що у процесі діяльності вирішується порядку трьохсот різних завдань з планування, обліку, контролю та аналізу роботи флоту. Серед планових завдань, що складають 40\% загальної кількості, більшість є оптимізаційними, оскільки при їх рішенні необхідно розглядати і порівнювати різні варіанти за попередньо обумовленими критеріями i вибирати той варіант, що забезпечує максимальну ефективність.

Принцип ієрархічності зв'язаний 3 тим, що планування експлуатаційних витрат транспортної компанії необхідно розглядати з позиції ієрархічної системи.

Принцип динамічності. Транспортний процес $є$ непостійним у часі і просторі. Зміна його стану відображає динамічність функціонування системи. Ця властивість виявляється важливою при плануванні роботи транспортної компанії, оскільки при цьому необхідно враховувати фактор часу. Якщо фактор часу в розрахунках не буде враховуватися, то можна 
отримати незадовільний результат через те, що моделі, які описують роботу водного транспорту, неадекватно відображають реальні умови експлуатації флоту і портів.

Реалізація принципів планування в транспортній компанії привела до поняття безперервне планування. Під безперервністю планування розуміється використання єдиної нормативної і методологічної бази для різного горизонту планування експлуатаційних витрат. Безперервне планування вимагає також складання календарного графіка за кожним судном транспортної компанії. Аналіз існуючих і перспективних методів планування експлуатаційних витрат у транспортній компанії показав необхідність впровадження адаптивної трьохрівневої системи планування: навігаційного, оперативного та рейсового рівнів.

Структура витрат суднохідної компанії наведена на рис. 2.

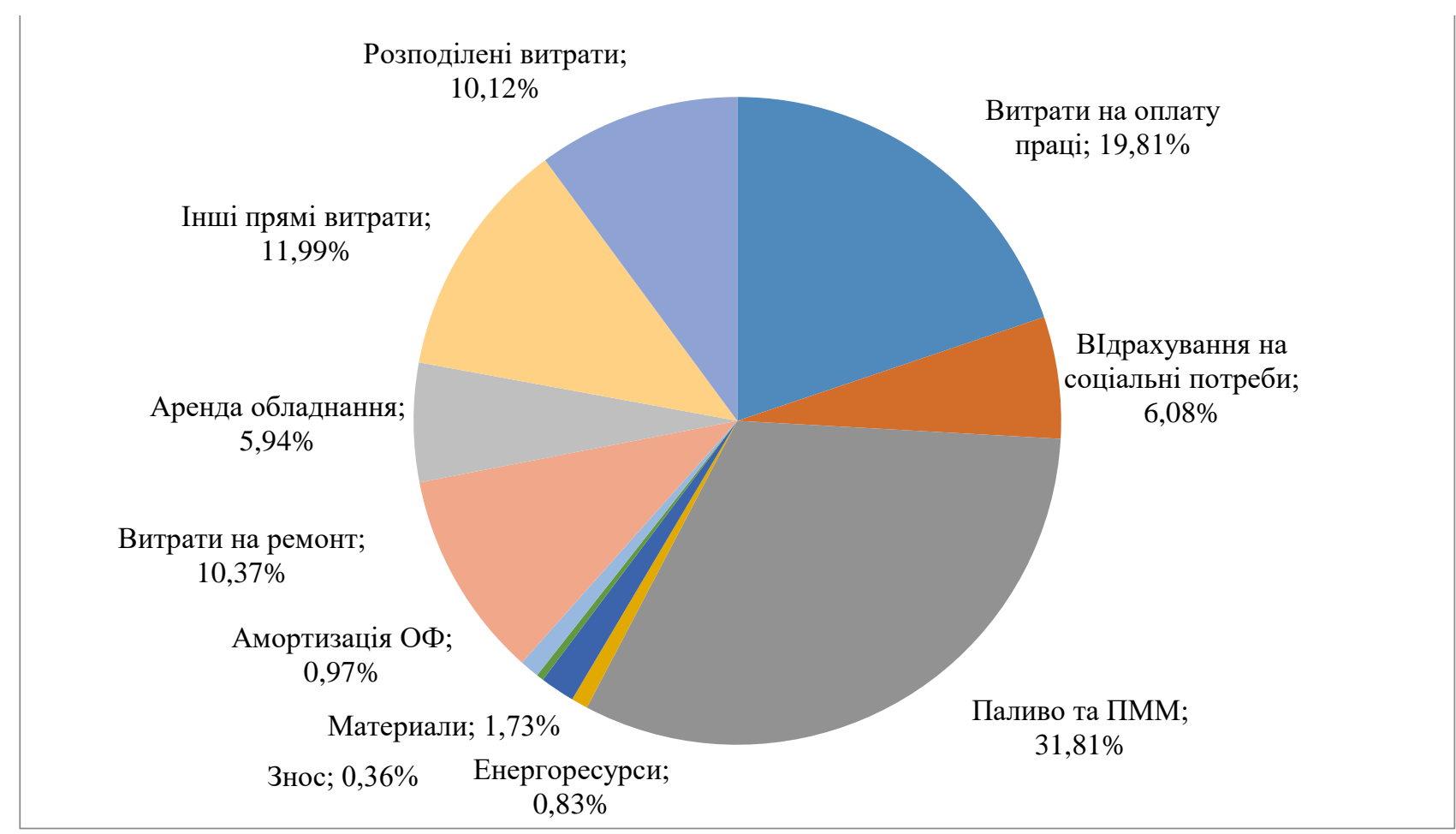

Рисунок 2 - Структура витрат в транспортній компанії

Наведені дані свідчать, що близько третини витрат у транспортній компанії відноситься до витрат на паливо. Необхідно відзначити, що для ведучих світових транспортних компаній, таких як AmericanLine, P\&O Ferries, HollandAmericaLine за результатами 2016-2018 рр. у структурі витрат паливо складає від 20 до 30\%. Таким чином, можна зробити висновок, що зниження витрат на паливо $є$ важливим завданням підвищення ефективності діяльності і конкурентноздатності сучасних транспортних компаній.

На сьогоднішній день при плануванні потреби палива в судноплавних компаніях установлюються норми витрати палива, виходячи з даних минулої навігації (з корегуванням на зміни обсягу роботи-вантажообігу) [10]

$$
V_{H}=\frac{\left(\sum_{i=1}^{n} V_{\phi_{i}}\right) \times\left(\sum_{j=1}^{m} A_{n p_{j}}\right)}{\sum_{i=1}^{n} A_{\phi_{i}}},
$$

де $V_{H}$ - планова потреба палива на навігацію, тис.т;

$V_{\phi_{i}}$ - фактична витрата палива на і-ій лінії перевезення суднохідної компанії за результатами минулої навігації;

$A_{n p_{j}}-$ прогнозний обсяг вантажообігу суднохідної компанії на навігацію на ј-ій лінії перевезення, тис.т;

$A_{\phi_{i}}$ - фактичний вантажообіг компанії на і-ій лінії перевезення; 
$n$ - кількість ліній перевезення в попередню навігацію;

$m$ - кількість ліній перевезення в плановану навігацію.

У загальному випадку $n \neq m$.

3 метою підвищення якості планування витрат на паливо використовується метод моделювання бізнес-процесів, в основі якого лежить опис процесу через дії. Процесний підхід до планування витрат на паливо дозволяє вибудувати логічний взаємозв'язок всіх елементів, властивий процесу планування від початку до його завершення. Моделювання повинне враховувати також зовнішні стосовно транспортної компанії процеси, які впливають на кінцевий результат планування. Однак, урахування значної кількості факторів, які впливають на процес планування витрат на паливо, може значно ускладнити модель i утруднити рішення поставленого завдання. Для уникнення надлишкового опису процесу планування рекомендується використовувати різні види моделювання залежно від досліджуваних елементів процесу.

Для планування витрат на паливо доцільно використовувати функціональне та імітаційне моделювання. Функціональне моделювання допускає опис процесу планування у вигляді чітко структурованих взаємозалежних функцій. При імітаційному моделюванні розглядається процес планування з урахуванням впливу різних зовнішніх і внутрішніх умов, 3 аналізом динамічних характеристик зміни процесу і з оцінкою ефективності розподілу ресурсів. Використання різних видів моделювання дозволяє сконцентрувати увагу на визначених характеристиках процесу моделювання.

Процесний підхід до планування включає кілька послідовних стадій [11]:

а) побудова вихідної моделі (0-ий) рівень, що характеризує в даний час на підприємстві порядок планування. У процесі моделювання визначаються ключові елементи і кордони процесу планування;

б) аналіз вихідної моделі, виявлення протиріч, дублювання дій, взаємозв'язків з іншими процесами. На цій стадії встановлюються необхідність зміни процесу планування і робиться уточнення вихідної моделі (уточнений 0-ий рівень);

в) побудова моделі, що відображає бажаний стан процесу планування, з урахуванням рекомендацій, спрямованих на підвищення його ефективності (1-ий рівень);

г) впровадження розробленої моделі процесу планування витрат на паливо у практику діяльності суднохідної компанії, апробація моделі і внесення необхідних коректувань.

На рис.3 наведена модель процесу планування експлуатаційних витрат на паливо в транспортній компанії (0-ий рівень).

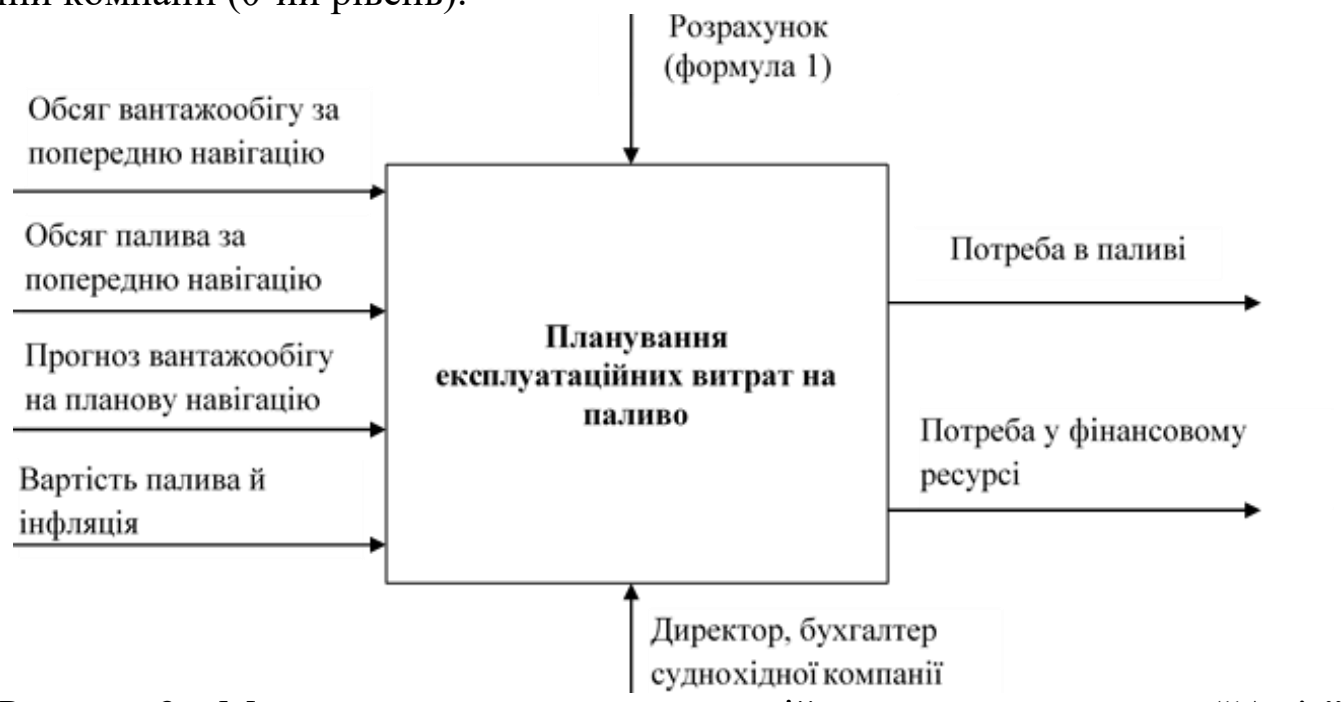

Рисунок 3 - Модель планування експлуатаційних витрат на паливо (“As is”)

Очевидно, що модель планування, наведена на рис. 3, має важливу перевагу - простоту розрахунків.Однак, вона не враховує важливих напрямків оптимізації витрати палива як:

а) оптимізація організації судноплавства в компанії шляхом зниження порожнього ходу, відповідність перевезеного вантажу характеристикам судна; 
б) нормування витрати палива не за паспортними даними судна, а по фактичним режимам його роботи і гідрологічним характеристикам суднового ходу;

в) оцінка ризику прогнозування для коректування плану;

г) адаптивна зміна плану при істотних змінах прогнозних параметрів плану від заданих.

При істотних змінах первісних прогнозних параметрів плану робиться коректування моделі процесу планування (адаптивна зміна плану). У цьому випадку, модель планування експлуатаційних витрат буде мати вигляд, зображений на рис.4 (уточнений 0-ий рівень).

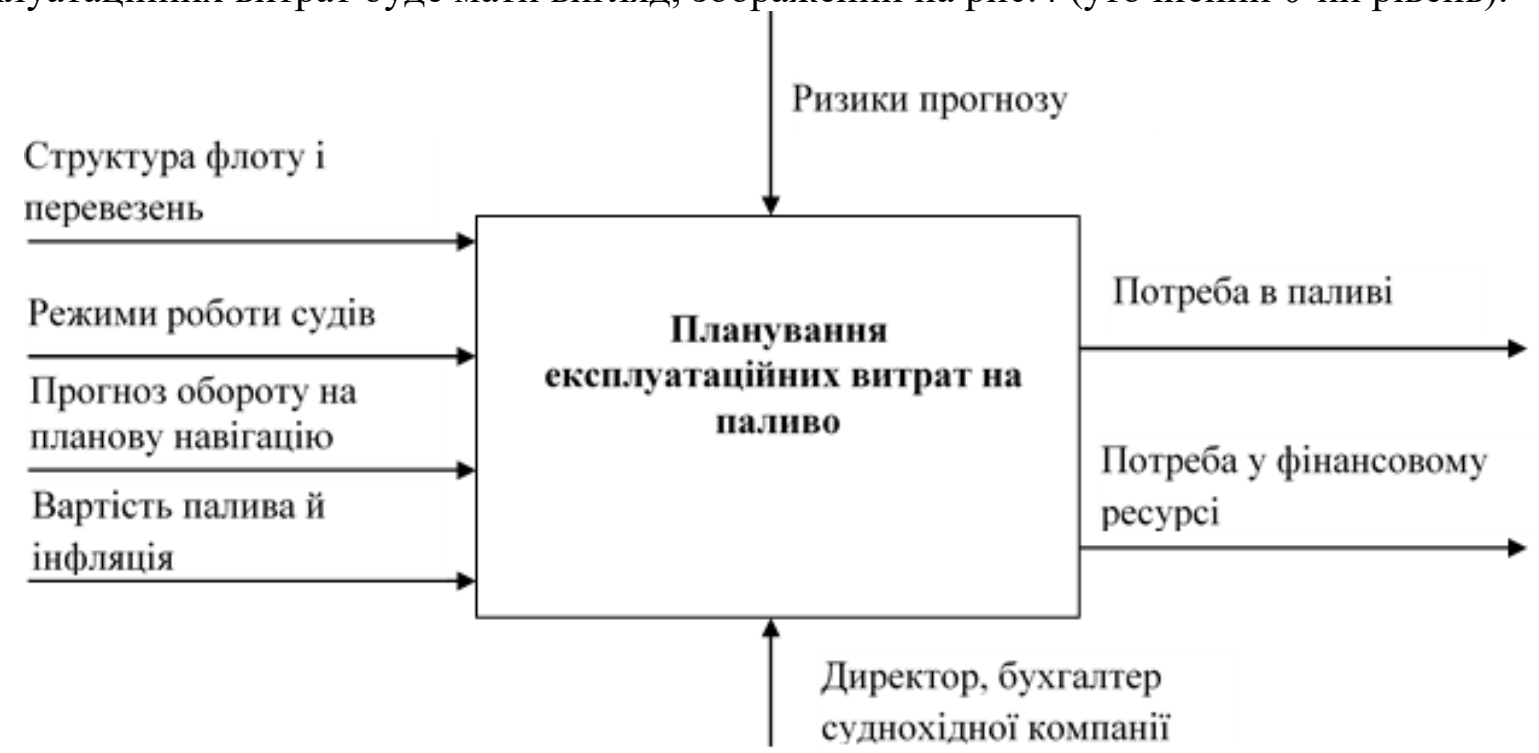

Рисунок 4 - Модель планування експлуатаційних витрат на паливо (“То be”)

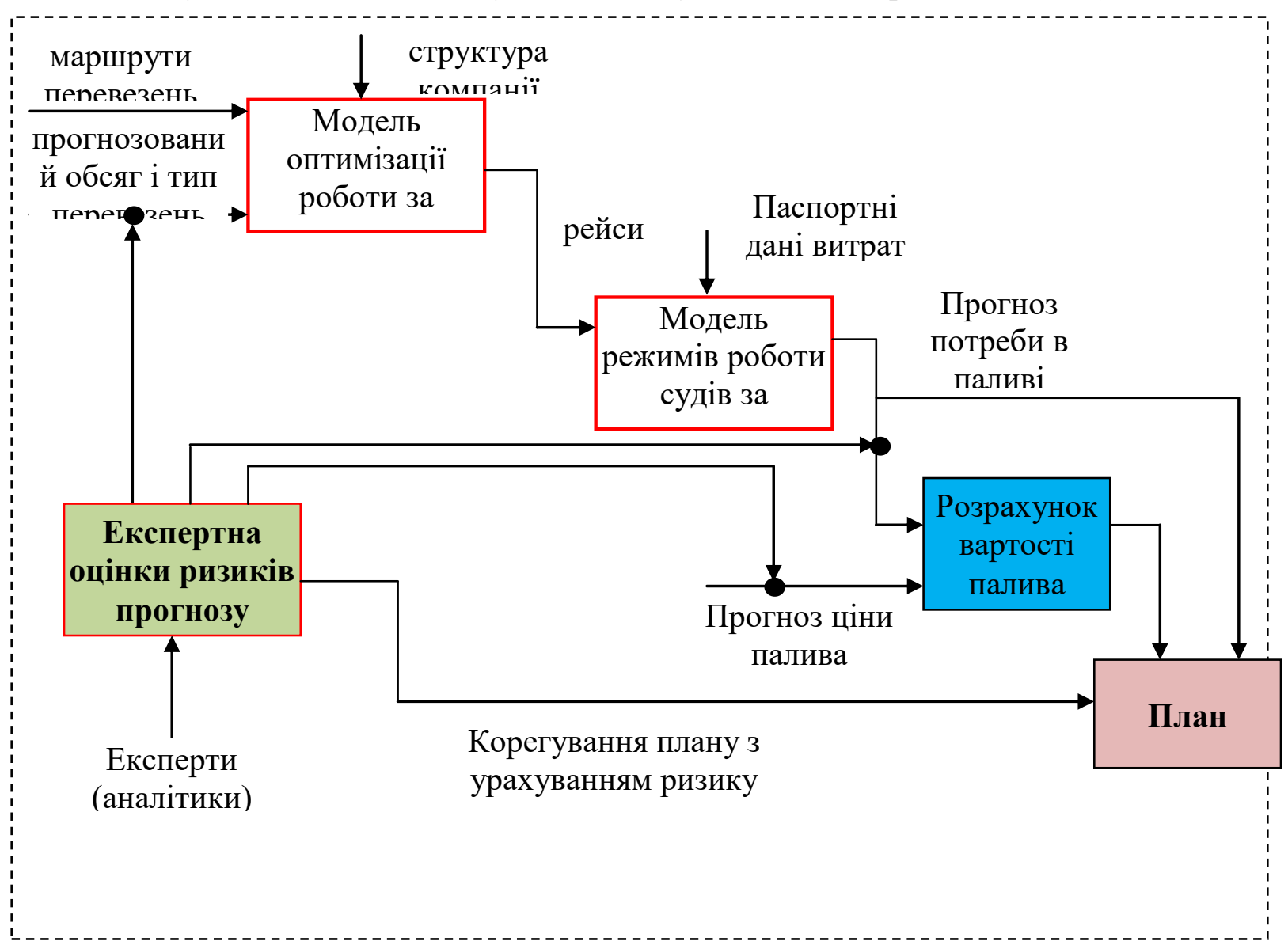

Рисунок 5 -Контекстна діаграма моделі планування експлуатаційних витрат на паливо (розроблена "Тo be")

Уточнена (удосконалена) модель планування не використовує (частково використовує) дані минулої навігації, тому вхідними параметрами для корегування процесу планування витрат на паливо $є$ : 

а) структура флоту і перевезень;
б) плановані обсяги і маршрути перевезень;
в) режими роботи суден для нормування витрати палива;
г) експертні оцінки прогнозних ризиків.

Оскільки планування експлуатаційних витрат на паливо є предметом дослідження, зроблена декомпозиція моделі, і на рис. 5 представлена модель 1-го рівня (“То be”) 3 урахуванням рекомендацій 3 удосконалення процесу планування. Розроблена модель планування експлуатаційних витрат на паливо в транспортній компанії дозволяє знизити ризики планування і прогнозування витрат палива, вибрати оптимальний режим роботи суден суднохідної компанії для зниження витрати палива за рахунок вибору оптимальної швидкості руху на ділянках шляху, внести адаптивність у планування, перейти від планування палива на навігацію до оперативного планування. Отримана модель дозволяє здійснити оперативне планування у формі календарного графіка (замість місячного i навігаційного планування) до кінця навігації за кожним судном окремо, а також за сукупністю основних і допоміжних місць витрат.

Розроблена модель дозволяє оперативно вносити зміни до плану при значних відхиленнях від прогнозу, тобто відсутність фіксації періоду для створення нового плану. Основою такого виду планування - $є$ нормування за кожним із суден компанії. При цьому треба відійти від планування витрат за даними минулої навігації. Процес планування здобуває риси адаптивності (здатності змінюватися, пристосовуюся до нових умов, факторів). Планування виконується не на плановий період (навігацію), а на менші часові інтервали залежно від роботи компанії. Крім цього існуючі резерви зниження витрат на паливо дозволяють вносити оперативні зміни в план.

Висновки. У статті проведено дослідження факторів, що впливають на витрату палива в транспортній компанії. Удосконалено організаційний метод зниження витрат на паливо в транспортних компаніях за рахунок зміни процесу планування.3 метою підвищення якості планування витрат на паливо запропоновано використовувати метод моделювання бізнеспроцесів, в основі якого лежить опис процесу через дії. Процесний підхід до планування витрат на паливо дозволяє вибудувати логічний взаємозв'язок всіх елементів, властивий процесу планування від початку до його завершення. Розроблена модель планування експлуатаційних витрат на паливо, яка удосконалює бізнес-процес планування.

Подальшими дослідженнями слід вважати розробку комплексних організаційно-технічних методів зниження витрат на паливо у транспортних компаніях.

\section{ЛIТЕРАТУРА}

1. Григорьев Е.А. Экономическая оценка ресурсосберегающих технологий работы речных судов: дис. ... канд.экон. наук: 08.00.05 / Григорьев Евгений Алексеевич. - Новосибирск, 2014. $-151 \mathrm{c}$.

2. Захаров Г.В. Техническая эксплуатация судовых дизельных установок /Г.В. Захаров.- М.: ТрансЛит, 2009.-256 с.

3. Grimmelius, H. Control optimization and load prediction for marine diesel engines using a mean value simulation model, environment and sustainability / H. Grimmelius, D. Stapersma // Proceedings of Ensus 2008 conference, Newcastle-upon-Tyne , 2008.

4. Шимко К.Н. Определение скорости движения судов и составов при техникоэкономических расчётах / К.Н. Шимко // Труды. Институт комплексных транспортных проблем при Госплане СССР. -1981. -Вып. 89. - С. 117-140.

5. Підвищення енергоефективності суден при роботі на коротких морських лініях (на прикладі суден з гвинтом регульованого кроку) :автореф. дис. ... канд. техн. наук : 05.22.20 / Тетяна Владиславівна Тарасенко; Одес. нац. мор. акад. - Одеса, 2015. - 24 с.

6. Лисняк Ю.А. Повышение эффективности использования топлива на морском флоте / Ю.А. Лисняк. - Севастополь: СевНТУ, 2005. - 38 с.

7. Методы оперативного планирования работы речного грузового флота на основе оптимального нормирования ходовой операции: монография /А.Ю. Платов. Н.Новгород: ФГОУ ВПО «ВГАВТ», 2009. - 155 с. 
8. Тверитин В.Н. Способ нормирования рас хода топлива / В.Н. Тверитин //Проблемы транспорта. - 2017. - № 7. - C. 12-13.

9. Michalsky, Jan P. A method for selection of parameters of shippropulsion system fitted with compromises crew propeller / Jan P. Michalsky // Polish Maritime Research, 4 (54), 2007. Vol. 14. - P. 3-6.

10. Инновационные технологии управления бизнес-процессами на транспорте. - М.: Дизайн. Информация. Картография, 2008. - 136 с.

11. Зуб А.Т. Стратегическое планирование. Системный подход / А.Т.Зуб, М.В Лактионов. М.: Генезис, 2011. - 848 с.

\section{REFERENCES}

1. Grigor'ev, E.A. (2014), Economic assessment of resource-saving technologies for the operation of river vessels: dissertation, Novosibirsk, $151 \mathrm{p}$.

2. Zakharov, G.V. (2009), "Tekhnicheskaya ekspluatatsiya sudovykh dizel'nykh ustanovok" [Technical operation of marine diesel engines], Trans Lit, Moscow, $256 \mathrm{p}$.

3.Grimmelius, H. and Stapersma, D. (2008) "Control optimization and load prediction for marine diesel engines using a mean value simulation model, environment and sustainability", Ensus 2008, Proceedings of Ensus 2008 conference, Newcastle-upon-Tyne.

4. Shimko, K.N. (1981), “Opredelenie skorosti dvizheniya sudov i sostavov pri tekhnikoekonomicheskikh raschetakh" [Determination of the speed of movement of ships and convoys during technical and economic calculations], Proceedings. Institute of Complex Transport Problems at the State Planning Commission of the USSR,Vol. 89, pp. 117-140.

5. Tarasenko, T. V. (2015), Improving the energy efficiency of ships when working on short sea lines (on the example of ships with a variable pitch propeller): Author's thesis, Odessa, $24 \mathrm{p}$.

6. Lisnyak, Yu.A. (2005), "Povyshenie effektivnosti ispol'zovaniya topliva na morskom flote" [Improving Navy Fuel Efficiency], SevNTU, Sevastopol, 38 p.

7.Platov, A.Yu. (2009) "Metody operativnogo planirovaniya raboty rechnogo gruzovogo flota na osnove optimal'nogo normirovaniya khodovoi operatsii: monografiya " [Methods of operational planning of the work of the river freight fleet based on the optimal rationing of the running operation: monograph],FGOU VPO «VGAVT», N. Novgorod, $155 \mathrm{p}$.

8. Tveritin, V.N. (2017), "Sposob normirovaniya raskhoda topliva" [The method of rationing fuel consumption], Transport issues Problemy transporta, No. 7, pp. 12-13.

9. Michalsky, Jan P. (2007), "A method for selection of parameters of ship propulsion system fitted with compromise screw propeller ", Polish Maritime Research, 4 (54), Vol. 14, pp. 3-6.

10. "Innovatsionnye tekhnologii upravleniya biznes-protsessami na transporte" (2008) [Innovative technologies for managing business processes in transport], Dizain. Informatsiya. Kartografiya, Moscow, $136 \mathrm{p}$.

11. Zub, A.T. and Laktionov, M.V. (2011) "Strategicheskoe planirovanie. Sistemnyi podkhod" [Strategic planning. Systems approach], Genezis, Moscow, 848 p.

\section{Дорошева А.А., Байрамова Е.В., Урум Н.С., Медведева Е.Ю. ОРГАНИЗАЦИОННЫЙ МЕТОД СНИЖЕНИЯ ЗАТРАТ НА ТОПЛИВО В ТРАНСПОРТНЫХ КОМПАНИЯХ}

Задача по минимизации затрат на топливо, становится первоочередной в системе управления затратами транспортных компаний. $B$ статье рассмотрень такие методические принципь планирования в судоходной компании, как сбалансированность, эффективность, вариантность, оптимальность, иерархичность, динамичность, $u$ планомерность. Доказана необходимость внедрения адаптивной трехуровневой системь планирования: навигаџионного, оперативного и рейсового уровней.

Рассмотрена структура расходов судоходной компании. Показано что около трети расходов в транспортных компаниях относится $\kappa$ расходам на топливо. $B$ статье доказано, что существуют технические и организаџионные методы снижения затрат на топливо в транспортных компаниях. Организационные методы связаны с изменениями в процессе планирования расходов в целом по компании. Показано, что на сегоднямний день 
при планировании потребности топлива в судоходных компаниях устанавливаются нормь расхода топлива, исходя из данных прошлой навигачии (с корректировкой на изменение объема работы-грузооборота). Предложено для планирования затрат на топливо использовать функциональное и имитационное моделирование.

Функииональное моделирование допускает описание процесса планирования в виде четко структурированных взаимосвязанных функиий. При имитационном моделировании рассматривается процесс планирования с учетом влияния различных внешних и внутренних условий, с анализом динамических характеристик изменения процесса и оценки эффективности распределения ресурсов. Использование различных видов моделирования позволяет сконцентрировать внимание на определенных характеристиках процесса моделирования. С целью повышения качества планирования расходов на топливо предложено использовать метод моделирования бизнес-процессов, в основе которого лежит описание процесса через действие. Прочессный подход к планированию расходов на топливо позволяет выстроить логическую взаимосвязь всех элементов, присущих процессу планирования, от начала до его завершения. Приведень существующий бизнес-процесс и разработаны усовершенствованный бизнес-прочесс планирования.

Ключевые слова: бизнес-процессы, расходы на топливо, организачионные методы, принциипы планирования, процессный подход, транспортная компания.

\section{Dorosheva A., Bayramova O., Urum N., Medvedeva O. ORGANIZATIONAL METHOD FOR FUEL COST REDUCTION IN TRANSPORT COMPANIES}

The task of minimizing fuel costs is becoming a priority in the cost management system of transport companies. The article discusses such methodological principles of planning in a shipping company as balance, efficiency, variability, optimality, hierarchy, dynamism, and orderliness. The necessity of introducing an adaptive three-level planning system: navigation, operational and route levels is proved.

The cost structure of the shipping company is considered. It is shown that about a third of expenses in transport companies are related to fuel costs. The article proves that there are technical and organizational methods for reducing fuel costs in transport companies. Organizational methods are associated with changes in the cost planning process for the whole company. It is shown that today, when planning the demand for fuel in shipping companies, fuel consumption standards are established based on data from previous navigation (adjusted for changes in the volume of work-cargo turnover). It is proposed to use functional and simulation modeling for fuel cost planning.

Functional modeling allows the description of the planning process in the form of clearly structured interrelated functions. In simulation modeling, the planning process is considered taking into account the influence of various external and internal conditions, with an analysis of the dynamic characteristics of the process change and an assessment of the efficiency of resource allocation. Using various types of modeling allows you to focus on certain characteristics of the modeling process. In order to improve the quality of fuel cost planning, it is proposed to use the method of modeling business processes, which is based on a description of the process through action. The process approach to planning fuel costs allows you to build a logical relationship between all the elements inherent in the planning process, from the beginning to its completion. The existing business process is presented and an improved business planning process is developed.

Keywords: business processes, fuel costs, organizational methods, planning principles, process approach, transport company. 